\title{
REPORT OF THE COMMITTEE ON STATUS OF PHARMACISTS IN THE GOVERNMENT SERVICE.
}

The efforts of our committee during the past year were chiefly devoted to an attempt to secure more equitable treatment for the men responsible for the pharmacentical service in the army.

Our members are already acquainted with the provisions of the Hughes-Bacon bill which was drafted in accord with the recommendations of the Surgeon-General, to the Chief of Staff (August 3, 1911) and introduced into the 62nd Congress by Representative Hughes and Senator Bacon. This bill is intended to promote the efficiency of the pharmaceutical division of the army known as the Hospital Corps. It provides for the creation of a higher class of non-commissioned officers to be known as sergeants-major, thereby affording opportunity for promotion such as already exists in other staff corps of the army. The bill also provides slight increases in pay for the lower grades of non-commissioned officers of this corps, so as to remove the discrimination against the Hospital Corps which has existed since the enactment of the Army Pay Bill of 1908.

Resolutions urging support of our bill were passed by this association also by the N. A. R. D. and by many state associations. The bill was favorably commented on by the Journal of the American Medical Association. (See Journal A. Ph. A., Vol. 1, pages $95,98,427$ and 1183.)

Notwithstanding the efforts of our committee assisted by our members no action was taken by the 62 nd Congress. With the co-operation of Dr. Payne, the bill was re-introduced in a slightly modified form at the 63rd Congress by Representative Hughes and Senator Bacon, being the first bill in the calendar in the House. Meanwhile, the Surgeon-General of the army again called attention to the need for this legislation in his annual report to the Chief of Staff for 1912. (See Journal of the A. Ph. A., Vol. 3, page 13.)

The bill was referred to the sub-committee on Military Affairs of the House, a hearing was granted; a brief and argument were filed. Dr. Payne, Mr. Hilton and Mr. Richardson appeared before the sub-committee. Colonel Gandy, the acting Surgeon-General, was called before the committee and the outlook seemed bright. At this time, we wrote to many members of the Association urging them to address communications to their senators and representatives asking support for this bill. Our members responded in a most satisfactory manner and in many cases enclosed favorable replies which they had received from their senators and congressmen. Then, when all seemed favorable, we found that our efforts were blocked. The sub-committee delayed its report and after some investigation we found that the opposition came from the Secretary of War whose powerful infuence has been sufficient to nullify our efforts up to this time.

Apparently there is now no prospect of favorable action on our bill. Evidently, we must draw up a new bill, one that will meet the approval of the Secretary of War before we can hope for success.

Our committee is in favor of asking commissions for pharmacists in the Hospital Corps. We believe that the military committees of Congress would consider such a proposal with favor. The advantage would be two-fold: it would provide a class of commissioned officers for the Army Hospital Corps-the only corps in the army which lacks such officers-and it would be a recognition of the professional status of pharmacists. We urge that the active efforts of our association be devoted to this cause.

While in Washington. Dr. Payne appeared before the comptroller of the treasury in behalf of the pharmacists of the L'nited States Public Health Service and urged an increase in their commutation of $\$ 25$ per month which has been granted within the past few weeks.

WV. B. DAY, Chairman. 